\title{
Government guidance on the promotion environmental enterprise security
}

\author{
Olena Dykan ${ }^{1}$, Volodymyr Nakonechny ${ }^{2}$, Maryna Mashchenko ${ }^{31}$, Olena Klimenko ${ }^{3}$, and \\ Ganna Obruch ${ }^{4}$ \\ ${ }^{1}$ Ukrainian State University of Railway Transport, Department of Management and Administration, \\ Feuerbakh sq. 7, 61050 Kharkiv, Ukraine \\ ${ }^{2}$ Kharkiv Regional State Administration, Department of Economics and International Relations, \\ Sumska str. 64, 61002 Kharkiv, Ukraine \\ ${ }^{3}$ Simon Kuznets Kharkiv National University of Economics, Department of Economic Theory, \\ Statistics and Forecasting, Nauky av. 9A, 61166 Kharkiv, Ukraine \\ ${ }^{4}$ Ukrainian State University of Railway Transport, Department of Economics and Management of \\ Industrial and Commercial Business, Feuerbakh sq. 7, 61050 Kharkiv, Ukraine
}

\begin{abstract}
Environmental security of the enterprise characterizes the state of protection of the enterprise and the environment, which allows you to maintain resistance to internal and external threats, providing the ability to solve problems of balanced development of the enterprise and improve the environment, contributes to the implementation of national concepts of socio-ecological and economic development and mechanisms to ensure it. The main tasks of the state to provide environmental security must be: substantiation of choice and decision-making in relation to the limited resources of nature and the environment as a specific public good; evaluation and comparison of costs and benefits in the environmental sphere, the rationale for the criteria and indicators of efficiency of nature protection actions; the analysis of market power for the environmental sector; consideration of external environmental effects (externalities); the development of methods for the estimation of an economic damage from pollution of natural environment; development of models of socioeconomic development that meet the requirements of environmental security.
\end{abstract}

\section{Introduction}

In modern management models, more and more attention is paid to the safety of enterprises. Problems of environmental security are the object of study both at the global and at the personal level. This problem is also actualized for enterprises, especially for natural resource users. The principles of sustainable development, green economy, environmentally friendly production became the impetus for theoretical research. However, the enterprise is a complex socio-ecological and economic system, which determines the complexity and diversity of development goals. This requires their coordination, search for compromises, which necessitated the combination of economic and environmental components in the justification of the concept of safety of industrial enterprises. The practice of their management requires appropriate tools for planning and implementation of measures aimed, on the one hand, at reducing the negative anthropogenic impact on the environment, conservation, reproduction and rational use of the natural resource potential of ecosystems, on the other, ensuring effective, profitable activities, which allows for

${ }^{1}$ Corresponding author: mmashchenko@ukr.net 
enhanced reproduction, competitiveness, implementation of the goals [1]. Therefore, environmental security becomes one of the basic criteria for assessing the effectiveness of enterprise management, and its provision is considered as one of the key processes of the enterprise.

\section{Main part}

To achieve the environmental security of the state, it is necessary to ensure the environmental security of the enterprise. The definition of "investment security of the enterprise" is broader than "economic security of the enterprise", as it includes three components: economic, social, environmental. The transformation of the socio-economic structure of Ukraine has led to changes in the mechanisms of enterprises and their management. To date, the provision of socio-ecological and economic security is an important issue. Entities in the course of their activities face various risks, the impact of which can not only lead to negative consequences, but also to bankruptcy. In turn, the knowledge of the nature of environmental security, its structure, quantitative and qualitative indicators to assess the level of environmental security will allow managers, economists and other professionals to ensure the safety of the enterprise. The need to ensure sustainable environmental safety of the enterprise is due to the stable functioning and success of each entity. The analysis of enterprises shows that financial, industrial, technological, investment and information sectors face acute problems related to activities. Their effectiveness also affects macroeconomic instability and structural imbalance [2]. Therefore, the enterprise, as the main link of the national economy, should demonstrate a significant interest in economic security in order to stabilize the financial situation of the country, the macroeconomic situation. The loss of production in the country, which changes the economic functions of the state, has led to a revision of the definition of "economic security" and emphasizes the need to address socio-environmental and economic threats of enterprises.

Environmental security of the enterprise characterizes the state of protection of the enterprise and the environment, which allows you to maintain resistance to internal and external threats, providing the ability to solve problems of balanced development of the enterprise and improve the environment, contributes to the implementation of national concepts of socio-ecological and economic development and mechanisms to ensure it. At the same time, socio-economic development has not only positive consequences: it is associated with the emergence of acute environmental problems and problems of the organization and implementation of socio-ecological and economic cooperation, the solution of which is in close relationship with changes in trends of natural character of economic development, without exception, in all sectors of the national economy.

It is important to identify the greatest threats and risks to the safe life of humanity in a timely manner. A comprehensive analysis and assessment of all processes related to the national security of Ukraine is needed. Adverse environmental conditions and the implementation of environmental safety precautions require appropriate legal, institutional and other measures. It is known that the complex impact of social, economic, environmental and other factors worsens human health and adversely affects the demographic situation in the country as a whole. At the present stage, it is necessary to prevent a global environmental disaster, the causes of which are the increase in the material needs of people, the expansion of economic activity and, thus, the increase in the impact of human activity on the environment. As a result, global environmental pollution, climate change, increasing the number of man-made disasters. In the context of globalization, the environmental and economic development of the social life of mankind requires recognition of the problems of conservation and rational use of natural resources, and at the same time requires constant harmony of the dynamics of their existence. The implementation of the 
mechanism of sustainable development brings together human (population), production (economy) and nature $[3,4]$. Therefore, in the present economy along with the social, technological and economic deals with environmental objectives, which must satisfy the conditions of preserving the ecological balance.

Environmental security is considered as a condition of the most effective use of corporate resources to prevent threats and ensure stable business activity in the present and future. In the resource-functional approach there are 7 functional components, as the main spheres of environmental security: intellectual; financial; technical and technological; political and legal environment; information; power.

The most significant impact on the state of the enterprise is carried out by the state. The state directly and indirectly regulates the activities of economic entities. Indirect regulation creates a system of incentives that creates stimulating conditions for the activities of enterprises (effective tax system, price policy, financial and credit policy). Direct state regulation includes the development of laws, regulations, measures that directly affect the activities of the market economy. The main directions of state regulation of the enterprise:

- implementation of Antimonopoly policy;

- providing a legal framework for enterprises;

- market regulation;

- investment policy;

- effective tax system;

- formation and development of business infrastructure;

- regulation of innovation processes;

- financial support in the form of state guarantees for foreign loans $[5,6]$.

That is why the state has one of the main roles in ensuring environmental security. In the form of indirect influence, the state formulates a system of incentives to create motivational conditions for rational socio-ecological and economic activity (effective tax, financial, credit, price, social and environmental policies) [7]. Direct state regulation provides the legislative and legal basis for the practical implementation of all aspects of the socio-ecological and economic activities of enterprises. At the same time, the state guidelines for ensuring the environmental security of enterprises are aimed at implementing the concept and mechanisms of sustainable development.

The main tasks of the state to provide environmental security must be $[8,9]$ : substantiation of choice and decision-making in relation to the limited resources of nature and the environment as a specific public good; evaluation and comparison of costs and benefits in the environmental sphere, the rationale for the criteria and indicators of efficiency of nature protection actions; the analysis of market power for the environmental sector; consideration of external environmental effects (externalities); the development of methods for the estimation of an economic damage from pollution of natural environment; development of models of socio-economic development that meet the requirements of environmental security.

The main tools of the complex mechanism of formation and implementation of state policy in the field of safety of socio-ecological and economic systems are [10]: environmental legislation; strategies, programs, plans for social development and environmental protection; licensing system in the environmental sphere; environmental assessment and assessment of the impact of environmental impact assessment on the state of the environment; environmental audit, environmental management systems, environmental labeling; social and environmental insurance; technical regulation, standardization and accounting in the field of environmental protection, nature management and ensuring environmental security; education and scientific support for the formation and implementation of state socio-environmentally oriented policies; social protection and control in the sphere of environmental protection; cross-sectoral partnership and inter- 
sectoral cooperation in social development and environmental protection; the "hot" line on social and environmental issues in public authorities at all levels; conferences, lectures, research, surveys, advertising, media and Internet coverage of social and environmental problems and ways to solve them; taxes, benefits, subsidies, credit rates, customs tariffs, depreciation rates to promote environmentally sound production and the introduction of environmentally sound technologies; international cooperation in the field of environmental protection and social security.

\section{Conclusion}

The concept of "economic security" within the framework of sustainable development is a narrower concept that explains security. The concept of security has a number of features inherent in the whole system of nature as a form of interaction between nature and society. Under the embodiment of environmental security at enterprises is understood not just the process of their gradual adaptation to external conditions, but a conscious purposeful change in the foundations of the functioning of one, a group or all enterprises, carried out within a relatively short period of time. The embodiment of environmental security at the enterprise is considered as a process of complex radical transformation of the organization, financial and economic, production and technical, information, management structures, property relations of economic entities in order to ensure the viability and development of the enterprise.

The priority directions of environmental security should be: resource-saving focus of technologies used in production in all industries, reducing the resource intensity of production; the creation of a unified system of environmental monitoring; reducing the level of environmental pollution throughout the country to environmental and health standards; deepening cooperation with the world community in solving environmental problems; the development of environmental education, culture and training of the population; prevention and elimination of environmental disasters, natural disasters, consequences of emergencies and accidents; development of scientific and technical potential in the field of ecology; accelerated development of industries that can increase export potential; improvement of the legal mechanism for regulating the interaction of public authorities at all levels; improvement of investment attractiveness; improvement of the business climate; ensuring energy independence; effective personnel policy in the environmental and economic sphere; formation of a sustainable system of national values and interests in the environmental and economic sphere.

\section{References}

1. M.A. Mashchenko, A.V. Lytvynenko. The bulletin of transport and industry economics. 61, 47-53 (2018)

2. M.A. Mashchenko. Upravlinnya rozvytkom. 2, 64-68 (2018)

3. V.L. Dykan. The bulletin of transport and industry economics. 34, 141-147 (2011)

4. G.V. Kozachenko, V.P. Ponomapev, O.M. Lyashenko. Ekonomichna bezpeka pidpryyemstva: sutnist ta mekhanizm zabezpechennya, Libra, 280 (2003)

5. O.Yu. Chubukova, O.V. Olshanska. Efektyvna ekonomika. 2, URL: http://www.economy.nayka.com.ua/?op=1\&z=3765 (2015)

6. A.O. Cherchyk. Visnyk Nacionaljnogho tekhnichnogho universytetu "Kharkivsjkyj politekhnichnyj instytut" (ekonomichni nauky). 28(1200), 51-54 (2016)

7. N. Avanesova, I. Volovelska, V. Maslova, T. Sukhorukova, Yu. Utkina. Inetrnational Journal of Engineering \& Technology. 7(4.3). 393-397 (2018)

8. O.S. Vlasyuk. Ekonomichna bezpeka Ukrajiny $v$ umovakh rynkovykh transformacij ta antykryzovogho reghuljuvannja, Academy of Financial Management, 
$474(2011)$

9. A.V. Tolstova, K.V. Khomenko. The bulletin of transport and industry economics. 63, 187-195 (2018)

10. M.A. Mashchenko. Efektyvna ekonomika. 11, URL: http://www.economy.nayka.com.ua/pdf/11-2018/65.pdf (2018) 